\title{
AMAZON PEATLANDS IN PERIL: A WARNING FOR GLOBAL WARMING
}

\author{
Rosa Maria Dias ${ }^{1 *}$, Raffael Marcos Tófoli², Taise Miranda Lopes ${ }^{1}$, Gustavo Henrique Zaia \\ Alves $^{1}$ \\ ${ }^{1}$ Universidade Estadual de Maringá, Pós Graduação em Ecologia de Ambientes Aquáticos Continentais, Laboratório de \\ Ecologia e Ictiologia, bloco H90, sala 002, Avenida Colombo, 5790. Maringá, PR, Brazil. \\ ${ }^{2}$ Instituto Federal Catarinense, Rodovia SC-135, km 125, Bairro Campo Experimental, CEP 89564-590, Videira, SC, Brazil. \\ Email:rmdias2003@yahoo.com.br (*corresponding author); biotofoli@gmail.com; taisemlopes@gmail.com; alvesghz@ \\ yahoo.com.br.
}

\begin{abstract}
The Amazon rainforest has been the target of several attacks, such as the massive increase in deforestation and fire outbreaks. The Amazon biome is not only composed of forest ecosystems, but also of an important carbon stock system called Peatland, which contains ca. 1 to 8 billion tons of carbon in its plants and soil. If burned, this peculiar ecosystem is likely to release tons of greenhouse gases, which may aggravate global warming. Therefore, our objective is to alert and anticipate problems associated with deforestation and fires in Peatland that, if not contained, may difficult global warming controlling, and the achievement of goals set in the Paris Agreement (which Brazil is a signatory).
\end{abstract}

Keywords: Brazilian government; greenhouse gas emissions; global warming; climate change.

The largest and most biodiverse tropical forest in the world continues to burn (Andrade 2019, Moutinho et al. 2020). Brazil is facing several cuts in priority sectors to maintain the country's sustainable development, such as science, technology, education, and the environment (Andrade 2019). The deterioration of the Environmental Ministry speeded up with the current far-right Brazilian government, which is dismembering and weakening fundamental inspection federal agencies subjected to the ministry (i.e. Instituto Brasileiro do Meio Ambiente e dos Recursos Renováveis - IBAMA and Instituto Chico Mendes de Conservação da Biodiversidade - ICMBio; Abessa et al. 2019). In 2019, several actions resulted in a cut in the Amazon fund by Germany and Norway (Boffey 2019), whose main objectives were to prevent deforestation, fires and to promote sustainable development in the region. In 2020, the COVID-19 pandemic has further exacerbated deforestation (Aragão et al. 2020), due to an even greater reduction in inspections by these already weakened agencies. Deforestation in 2019 and early 2020 left fuel for huge fires on the forest floor in the dry season, which begun in late June (Moutinho et al. 2020).

For many scientists, there is no doubt that Brazil's fires are related to deforestation for agriculture and pasture for cattle (Barlow et al. 2019, Escobar 2019). The fires has consumed the Amazon region and part of the Pantanal, reaching the border of Brazil, Paraguay, Bolivia, and Peru. It swept approximately 20,000 hectares of vegetation (Escobar 2019, Martinez 2019, Rebecca Lai et al. 2019, Madeiro 2019), part of indigenous reserves and protected areas (Mortara et al. 2020). In 2020, deforestation in the Amazon 
increased $51 \%$ in the 1st quarter, a record for the period (Amaral 2020). If deforestation continues to progress, the burning season tends to be increasingly severe. A large volume of deforested areas in 2019 stopped being burned due to the rainy season in December, and this unburned organic matter, added to what was deforested in early 2020, may create a massive quantity of dry matter which can be the trigger for an even greater burning (Moutinho et al. 2020).

The effects of Amazon deforestation and the consequent fires are not only local, but it extends to regional and global scales with unprecedented environmental, political, and socioeconomic consequences. The very first fire's effect was seen in the most populous Brazilian city, São Paulo, when a dark cloud covered the city, which is at least $1500 \mathrm{~km}$ far from Amazon biome (Alencar et al. 2020). Now, the southern region of Brazil is experiencing severe drought, the most intense in recent years (NASA 2020). This scenario may have been aggravated by the large losses of forests in the past two years. Besides its high biodiversity, the Amazon rainforest also aids in controlling the planet's temperature and rainfall in various regions of South America, which supports several ecosystems in addition to economic activities such as hydroelectric energy generation (responsible for $80 \%$ of total energy consumed in Brazil) and agribusiness (Fearnside 2008, Baker \& Spracklen 2019). Therefore, ecosystem services offered with the maintenance and conservation of rainforests are not only good for in terms of preserving the biodiversity, but also economically more advantageous than its degradetion (Waldron et al. 2020).

Another worrying fact is the degradation of forest-associated ecosystem, such as the peatland ecosystems of the Amazon, concentrated in Western and Central Amazon, mainly in Peru and Brazil (Román-Cuesta et al. 2011, Lähteenoja et al. 2012, Lähteenoja et al. 2013, Draper et al. 2014, Gumbricht et al. 2017). Increased deforestation due to land use make these wet ecosystems susceptible to fire (Adrianto et al. 2020). The peatlands comprise ecosystems that concentrate large amounts of carbon reserves, storing 1-8 PgC ( $1 \mathrm{Pg}=1$ billion tons), in an area of approximately $35,000 \mathrm{~km}^{2}$ (Lähteenoja et al. 2012). Tropical peatlands account for a substantial part of global soil carbon storage (Murdiyarso et al. 2017) and are very important in terms of potential regional greenhouse gas fluxes, as land-use change can quickly return their carbon stocks to the atmosphere (Lilleskov et al. 2019, Gewin 2020). If burned, peatlands may become a new source of carbon dioxide to the atmosphere and highly contribute to the acceleration of global warming.

It already happened in Indonesia, in 1997 (Page et al. 2002), when after a period of drought and anthropic fires, peatlands emitted between 0.81 and 2.57 gigatonnes of carbon into the atmosphere, which is equivalent to 13 to 40 percent of the world's annual fossil fuels emissions (Draper et al. 2014). In 2015, Indonesia experienced one of the largest fire seasons in its history, exceeding 1997 emissions (Kiely et al. 2019). The concern about gas emissions in peatlands and its effects on global warming is so high that, in March 2019, the United Nations adopted the first resolution to protect these ecosystems (United Nations 2019).

The peatlands in the Brazilian Amazon are distributed mainly in the Amazonas and Amapá states (Lähteenoja et al. 2013, Gumbricht et al. 2017) (Figure 1). Both states are affected by fires and other anthropic impacts. In Amapá state for example, the Lago Piratuba Biological Reserve (Gumbricht etal.2017) has suffered major impacts from buffalo rearing (Figure 1). Buffaloes are bred free and advance further into the reserve to graze in better pastures. Soil compaction, landscape changes, and fires caused by pasture renewal are some of the negative results due to the lack of an adequate management plan. In the last 10 years, two major fires have taken place in this region, reaching the peatlands: one in 2012, in which an area of 26,000 hectares was affected and another in 2014, burining an area of 3,000 thousand hectares (G1 2014, ICMBio 2014). The additive effects of deforestation arising from the "arc of deforestation" (IPAM 2015) can affect other parts of the Amazon (as well as the Cerrado), reducing precipitation and making the regional climate drier (Costa \& Pires 2009).

Our goal here is to alert fires events, especially those that might affect peatlands, which would jeopardize any measures of projection taken to contain global warming and promote biodiversity conservation, includinginternational agreements 


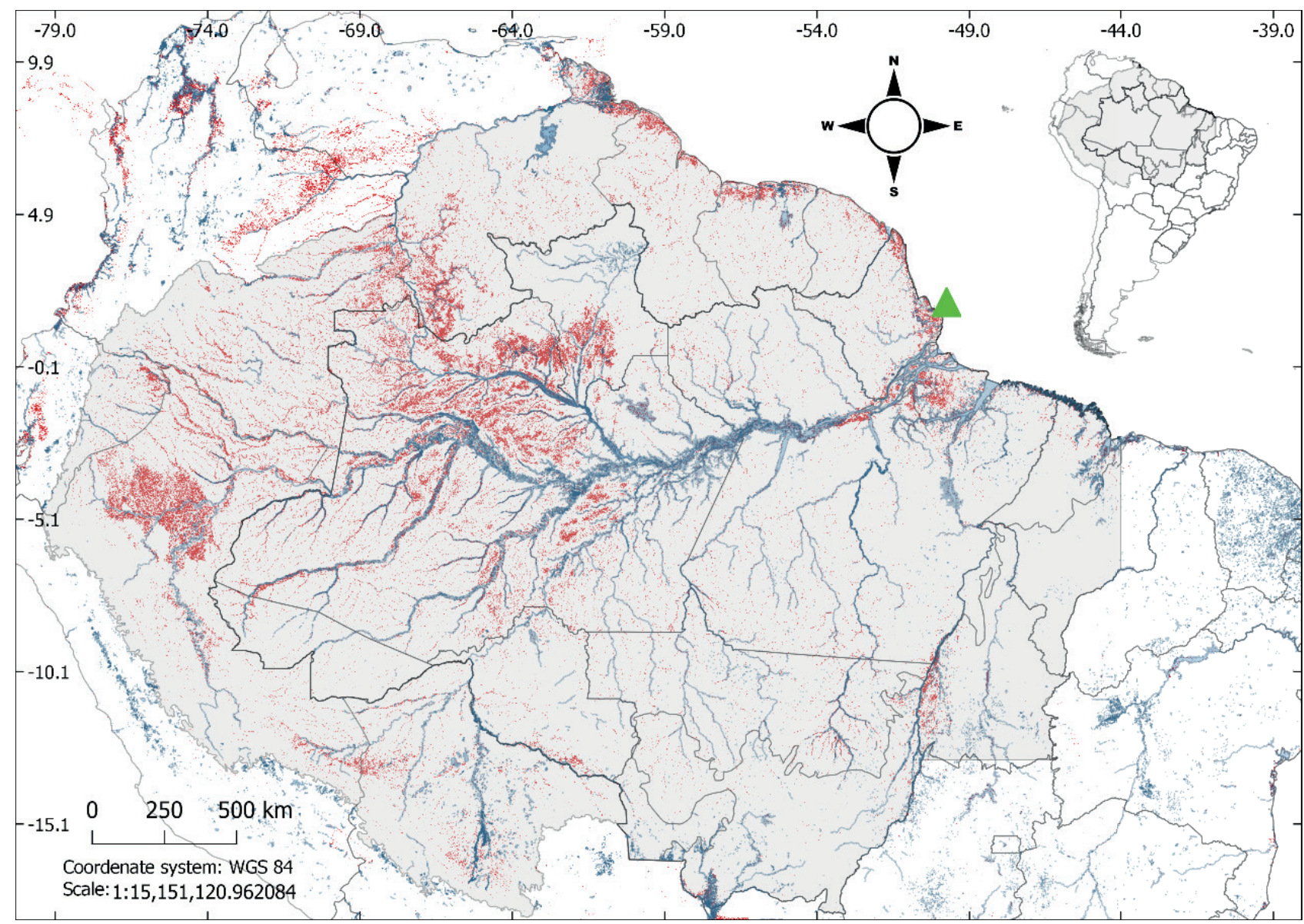

Figure 1. Distribution of the peatlands (in red) in the context of the Amazon rainforest region (in gray), rivers and other waterbodies (in blue) in northern South America, and solid lines represent political limits. The Green triangle indicates the Lago Piratuba Biological Reserve in Amapá State (Brazil), where in the last 10 years, two major fires have taken place in this region, reaching the peatlands. This map was prepared using the Center for International Forestry Research (CIFOR) database, available at: <http://www.cifor.org/global-wetlands/>.

that Brazil have already rectified to accomplish, such as the Paris Agreement (United Nations Climate Change 2016) and the CDB Aichi target 8 (Convention on Biological Diversity 2010).

For the conservation of the Amazon, it is necessary to strengthen cooperative and strategic initiatives, such as the Amazon Cooperation Treaty Organization, composed of countries that share the Amazon territory: Brazil, Bolivia, Colombia, Ecuador, Guyana, Peru, Suriname, and Venezuela (Ministério das Relações Exteriores 2019). Countries need to continue investing financially in environmental projects such as the Forest Coverage Monitoring in the Amazon Region Project, implemented since mid-2011 in partnership with the National Institute for Space Research (INPE) (Ministério das Relações Exteriores 2019). The main goals of this project are related to forest management (deforestation, land occupation, changes in land use, and sustainable forest management), seeking to strengthen the common dialogue among Member Countries, as well as the development of information related to the monitoring of forest cover carried out by the National Observation Rooms installed in the countries in 2012 (OTCA 2012). Also, countries need to ratify the goals of the Paris Agreement, which aims to prevent the effects of climate change and reduce greenhouse gas emissions.

\section{REFERENCES}

Abessa, D., Famá, A., \& Buruaem, L. 2019. The systematic dismantling of Brazilian environmental laws risks losses on all fronts. Nature Ecology \& Evolution, 3, 510-511. DOI: 10.1038/s41559-019-0855-9

Adrianto, H. A., Spracklen, D. V., Arnold, S. R., 
Sitanggang, I. S., \& Syaufina, L. 2020. Forest and Land Fires Are Mainly Associated with Deforestation in Riau Province, Indonesia. Remote Sensing, 12(3), 1-12. DOI:10.3390/ rs12010003

Alencar A., Moutinho, P., Arruda, V., \& Silvério, D. 2020. Amazonas em chamas - O fogo e o desmatamento me 2019 e o que vem em 2020. Nota técnican ${ }^{\circ}$ 3. Brasília:Instituto de Pesquisa Ambiental da Amazônia, 2020. Disponível em: https://ipam.org.br/bibliotecas/amazoniaem-chamas-3-o-fogo-e-o-desmatamentoem-2019-e-o-que-vem--em-2020.

Amaral, A. C. 2020. Desmate na Amazônia aumenta $51 \%$ no $1^{\circ}$ trimestre e bate recorde do período. https://ambiencia.blogfolha.uol. com.br/2020/04/13/desmate-na-amazoniaaumenta-51-no-1o-trimestre-e-bate-recordedo-periodo/ (accessed 15.06.2020).

Andrade, R. O. 2019. Alarming surge in Amazon fires prompts global outcry. https://www. nature.com/articles/d41586-019-02537-0 (accessed 02.06.2020).

Aragão, L. E. O. C., Silva Junior, C. H. L., \& Anderson, L. O. 2020. O desafio do Brasil para conter o desmatamento e as queimadas na Amazônia durante a pandemia por COVID-19 em 2020: implicações ambientais, sociais e sua governança. São José dos Campos. p. 34. SEI/INPE: $\quad 01340.004481 / 2020-96 / 5543324$. DOI: $10.13140 /$ RG.2.2.11908.76167/1

Baker, J. C. A., \& Spracklen, D. V. 2019. Climate Benefits of Intact Amazon Forests and the Biophysical Consequences of Disturbance. Frontiers in Forests and Global Change. DOI: 10.3389/ffgc.2019.00047

Barlow, J., Berenguer, E., Carmenta, R., \& França, F. 2019. Clarifying Amazonia's burning crisis. Global Change Biology, 26(2), 319-321. DOI: $10.1111 /$ gcb.14872

Boffey, D. 2019. Norway halts Amazon fund donation in dispute with Brazil, https:// www.theguardian.com/world/2019/aug/16/ norway-halts-amazon-fund-donationdispute-brazil-deforestation-jair-bolsonaro (accessed 02.06.2020).

Convention on Biological Diversity. 2010. Aichi Biodiversity Targets, https://www.cbd.int/sp/ targets/ (accessed 06.06.2020).

Costa, M. H., \& Pires, G. F. 2009. Effects of Amazon and Central Brazil deforestation scenarios on the duration of the dry season in the arc of deforestation. International Journal of Climatology, 30(13), 1970-1979. DOI: 10.1002/ joc. 2048

Draper, F. C., Roucoux, K. H., Lawson, I. T., Mitchard, E. T. A., Coronado, E. N. H., Lähteenoja, O., Montenegro, L. T., Sandoval, E. V., Zaráte, R., \& Baker, T. R. 2014. The distribution and amount of carbon in the largest peatland complex in Amazonia. Environmental Research Letters, 9, 124017. DOI:10.1088/1748-9326/9/12/124017

Dubroeucq, D., \& Volkoff, B. 1998. From oxisols to spodosols and histosols: evolution of the soil mantles in the Río Negro basin (Amazonia). Catena, 32, 245-280.

Escobar, H. 2019. Deforestation in the Amazon is shooting up, but Brazil's president calls the data 'a lie' https://www.sciencemag. org/news/2019/07/deforestation-amazonshooting-brazil-s-president-calls-data-lie (accessed 03.06.2020).

Fearnside, P. M. 2008. The roles and movements of actors in the deforestation of Brazilian Amazonia. Ecology and Society, 13(1), 23.

G1. 2014. Incêndio na reserva do Lago Piratuba, no Amapá, atinge 3 mil hectares. http://g1.globo. com/ap/amapa/noticia/2014/11/incendio-nareserva-do-lago-piratuba-no-amapa-atinge3-mil-hectares.html (accessed 18.09.2020).

Gewin, V. 2020. How peat could protect the planet. Nature, 578, 204-208. DOI: 10.1038/ d41586-020-00355-3

Gumbricht, T., Roman-Cuesta, R. M., Herold, L. V. M., Wittmann, F., Householder, E., Herold, N., \& Murdiyarso, D. 2017. An expert system model for mapping tropical wetlands and peatlands reveals South America as the largest contributor. Global Change Biology, 23 (9), 3581-3599. DOI: 10.1111/gcb.13689

ICMBio. 2014. Incêndio criminoso atinge Reserva Biológica no Amapá. https://www.icmbio.gov. br/portal/ultimas-noticias/5196-incendiocriminoso-atinge-reserva-biologica-noamapa (accessed 16.09.2020).

IPAM. 2015. Arco do desmatamento. https://ipam. org.br/glossario/arco-do-desmatamento/ (accessed 06.10.2020).

Kiely, L., Spracklen, D. V., Wiedinmyer, C., 
Conibear, L., Reddington, C. L., ArcherNicholls, S., Lowe, D., Arnold, S. R., Knote, C., Khan, M. F., Latif, M. T., Kuwata, M., Budisulistiorini, S. H., \& Syaufina, L. 2019. New estimate of particulate emissions from Indonesian peat fires in 2015. Atmospheric Chemistry and Physics, 19, 11105-11121. DOI: 10.5194

Lähteenoja, O., Flores, B., \& Nelson, B. 2013. Tropical Peat Accumulation in Central Amazonia. Wetlands, 33, 495-503. DOI: 10.1007/s13157-013-0406-0

Lähteenoja, O., Reátegui, Y. R., Räsänen, M., Torres, D. D. C., Oinonen, M., \& Page, S. 2012. The large Amazonian peatland carbon sink in the subsiding Pastaza-Marañón foreland basin. Peru Global Change Biology, 18(1), 164178. DOI: 10.1111/j.1365-2486.2011.02504.x

Lilleskov, E., McCullough, K., Hergoualc'h, K., Torres, G. C., Chimner, R., Murdiyarso, D., Kolka, R., Bourgeau-Chavez, L., Hribljan, J., Pasquel, J. A., \& Wayson, C. 2019. Is Indonesian peatland loss a cautionary tale for Peru? A two-country comparison of the magnitude and causes of tropical peatland degradation. Mitigation and Adaptation Strategies for Global Change, 24, 591-623. DOI: 10.1007/ s11027-018-9790-3

Madeiro, C. 2019. Inpe: Fogo queimou área de 4,2 mi campos de futebol na Amazônia em agosto. https://noticias.uol.com.br/meio-ambiente/ ultimas-noticias/redacao/2019/09/03/inpefogo-queimou-area-de-34-mi-camposde-futebol-na-amazonia-em-agosto.htm (accessed 03.06.2020).

Martinez, M. R. 2019. Satellite images show expanding fire at South American tri-border area. https://www.euronews.com/2019/08/27/ satellite-images-show-expanding-fire-atsouth-american-tri-border-area (accessed 06.06.2020).

Ministério das Relações Exteriores. 2019. Organização do Tratado de Cooperação Amazônica. http://www.itamaraty.gov.br/pt$\mathrm{BR} /$ politica-externa/integracao-regional/691organizacao-do-tratado-de-cooperacaoamazonica-otca (accessed 04.06.2020).

Mortara, S. R., Rosa, P., Ribeiro, J. W., SánchezTapia, A., Ferreira, G. C., Fernandez, E., Siqueira, M. F., \& Martinelli, G. 2020.
Amazonian fires endanger threatened plants and protected áreas. Frontiers in Ecology and the Environment, 18(4),177-178. DOI: 10.1002/ fee.2197

Moutinho, P., Alencar, A., Arruda, V., Castro, I., \& Artaxo, P. 2020. Nota técnica no 3: Amazônia em Chamas - desmatamento e fogo em tempos de covid-19. Instituto de Pesquisa Ambiental da Amazônia. Brasília. Disponível em: https://ipam.org.br/bibliotecas/amazoniaem-chamas-4-desmatamento-e-fogo-emtempos-de-covid-19-na-amazonia/

Murdiyarso, D., Roman-Cuesta, R. M., Verchot, L., Herold, M., Gumbricht, T., Herold, N., \& Martius, C. 2017. New map reveals more peat in the tropics. Center for International Forestry Research (CIFOR), 189. DOI: 10.17528/ cifor/006452

NASA. 2020. Measuring Drought in South America. https://earthobservatory.nasa.gov/ images/146537/measuring-drought-in-southamerica_(accessed 06.10.2020).

OTCA 2012. Projeto de Monitoramento da Cobertura Florestal. http://www.otca-oficial. info/projects/details/12 (accessed 06.10.2020).

Page, S. E., Siegert, F., Rieley, J. O., Boehm, H. D. V., Jaya, A., \& Limin, S. 2002. The amount of carbon released from peat and forest fires in Indonesia during 1997. Nature, 420, 61-65. DOI: 10.1038/nature01131

Rebecca Lai, K. K., Lu, D., \& Blacki, M. 2019. What satellite imagery tells us about the Amazon rain forest fires, https://www.nytimes.com/ interactive/2019/08/24/world/americas/ amazon-rain-forest-fire-maps.html (accessed 03.06.2020).

Román-Cuesta, R. M., Salinas, N., Asbjornsen, H., Oliveras, I., Huamand, V., Gutiérrez, Y., Puelles, L., Kala, J., Yabar, D., Rojas, M., Astete, R., Jordán, D. Y., Silman, M., Mosandl, R., Weber, M., Stimm, B., Günter, S., Knoke, T., \& Malhi, Y.. 2011. Implications of fires on carbon budgets in Andean cloud montane forest: The importance of peat soils and tree resprouting. Forest Ecology and Management, 261(11),19871997. DOI: 10.1016/j.foreco.2011.02.025

Suszczynski, E. F. 1984. The peat resources of Brazil. Proceedings of the 7 th International Peat Congress, Dublin 1, 468-492.

United Nations Climate Change. 2016. The Paris 
6 | Amazon peatlands in peril

Agreement - Status of Rarification. https:// unfccc.int/process/the-paris-agreement/ status-of-ratification (accessed 06.06.2020).

United Nations. 2019. Conservation and sustainable management of peatlands. https:// papersmart.unon.org/resolution/uploads/ k1900729.pdf (accessed 03.10.2020).

Submitted: 26 June 2020 Accepted: 11 November 2020 Pubished on line: 04 December 2020 Associate Editor: Thiago Laranjeiras 